\title{
Dynamics of the daily course of water temperature in Polish lakes
}

\author{
Rajmund SKOWRON $^{\text {ABCDF }}$, Adam PIASECKI ${ }^{\text {BCE }}$
}

Nicolaus Copernicus University, Faculty of Earth Science, ul. Lwowska 1, 87-100 Toruń, Poland; e-mail: rskowron@umk.pl, adm.piasecki@gmail.com

For citation: Skowron R., Piasecki A. 2016. Dynamics of the daily course of water temperature in Polish lakes. Journal of Water and Land Development. No. 31 p. 149-156. DOI: 10.1515/jwld-2016-0046.

\begin{abstract}
The study focuses on short-term changes in surface water temperature in Polish lakes, and is based upon the experimental measurements of water temperature conducted every 60 minutes during the years 1971-2015. 19 lakes were selected on the grounds of their morphometric properties. The examinations were carried out in the system of expeditionary measurements (up to 8 days) and stationary measurements (over 2 months), and included temperature of surface water and its vertical distribution. The analysis of the results showed that temperature differences of water (daily amplitudes) were observed in both time and spatial distribution. The biggest differences in water temperature occurred during spring warming, and often reached $4-5^{\circ} \mathrm{C}$, while rarely exceed $2^{\circ} \mathrm{C}$ in the remaining periods of the yearly cycle. The mean day value occurs twice; in the morning between 8:00 (7:00 GMT) and 11:00 (10:00 GMT), and in the evening at 20:00 (19:00 GMT) and 22:00 (21:00 GMT). Daily changes in the vertical distribution of water temperature are clearly visible down to the depth of 2.5-3.5 m, whereas are just perceptible to the depth of 5.5-7.0 m.
\end{abstract}

Key words: lakes, litoral, short-term changes, water temperature

\section{INTRODUCTION}

The concepts of water cyclicity, seasonality and periodicity are widely known in limnological literature. They result from solar insolation and the accumulation of all the processes undergoing in lake systems. The daily cycle of water temperature, which is also the shortest link of energy circulation, is particularly interesting. Among all the processes that occur in the lake system the daily cycle of water temperature and changeability of heat resources are of big interest. This course is simultaneously the shortest link (cycle) of long-term changes (seasonal, yearly). The rhythm is characterised by cyclic ad sinusoidal course, delimited by a 24-hour period.

The studies on the daily course of water temperature in Polish lakes were initiated in the midtwentieth century and continued in later years. Meas- urements were carried out mainly on the Masurian lakes (Niegocin, Tałty, Mikołajskie and Śniardwy) [KONDRACKI 1952].

The research by GIEYSZTOR [1960], which shows variability of water temperature in lakes and difference of thermal conditions in the littoral and pelagial zones in Lake Mikołajskie and Lake Tałty [CHOJNOWSKI 1967]. In terms of vertical density stability of water column, the investigations carried out by GRZEŚ [1976] on Lake Gopło treated daily temperature as a measure of stratification stability and its daily cycle. As for shallow water bodies of a pond type, SZUMIEC [1984] presented this problem against actionometric observations. The author states that a single measurement is sufficient to obtain the value of water temperature close to the mean day value if it is taken between 9:00 (8:00 GMT) and 10:00 (9:00 GMT). On the other hand, according to DMOCHOWSKI 
et al. [1988] the mean depth of water bodies plays the most important role in the dynamics of daily water temperature in lakes. The investigations into a daily rhythm of water temperature conducted in the lakes with various morphometric properties by SKOWRON [1999; 2000a, b; 2011] had a considerably wider range. The research on the daily course of water temperature conducted on the mountain lakes, such as: Morskie Oko and Wielki Staw in the Karkonosze Mountians is also important [ŁYCZKOWSKA 2009]. This study constitutes the widest aspect of the investigations carried out in this direction on 19 Polish lakes.

The objective of the research is to present the dynamics and properties of the daily course of surface water temperature in the lakes with various morphometric conditions located in the Polish Lowland, and determine the reasons for its diversity.

\section{MATERIALS METHODS AND STUDY AREA}

As a big number of measurements of daily course of water temperature in the lakes concerns the surface layer, it is necessary to specify what surface layer means. Hence, the lake surface layer is the most susceptible element in the lake system, susceptible to changes in meteorological conditions. Basic processes and mechanisms occur there, and these shape dynamics and regime of the system [LANGE 1978]. Water surface in lakes constitutes a boundary layer through which there is an exchange of energy and mass between the lake and its surrounding area, it is a zone of solar radiation absorption and water circulation. Mechanisms shaping thermal structures of water take place in this layer, and these affect the thermal balance and hydrological regime of the lake [SKOWRON 2011]. With respect to thermal conditions "the surface layer in the lake" is a layer with the thickness from 1.0 to $1.5 \mathrm{~m}$, for which the measurement taken at the depth of $0.4-0.6 \mathrm{~m}$ expresses the character of the daily and seasonal course of water temperature in the best way [SKOWRON 1999; $2000 \mathrm{a}, \mathrm{b}$ ].

The research on the daily course of water temperature in the lakes were conducted in the system of expeditionary and stationary measurements. Expeditionary (short-term) research was carried out over 5-8 days (in the years 19712015) in different zones of the lake (most frequently in the littoral, more rarely in the pelagial zones). These examinations were conducted in the surface layer and in the vertical distribution. The lakes selected for the study are located in the different regions of the Polish Lowland (lakes: Więcborskie, Brzeźno, Ostrowite, Świekatowskie, Gopło, Dzierzgoń, Wysokie Brodno, Bachotek, Jeziorak, Babię- ty Wielkie, Głębokie, Hańcza, Wigry, and Gaładuś) (Fig. 1). Stationary (long-term) measurements covering periods longer than 2 months were carried out both in the littoral and pelagial zones. The measurements in the pelagial zone were taken at the anchored measurement stations ad on the evaporimeter rafts (lakes: Sławskie, Łebsko and Raduńskie Górne). The stationary measurements were also conducted in lakes: Bachotek (2011, 2012), Hańcza (2011, 2013), Sławskie (2012), Okmin (2013), Łebsko (2012), Raduńskie Górne (2012), Brzeźno, Ostrowite and Starokiejkuckie. Thermal probes RTW8-042 and temperature sensors "Termio" were used for the purpose of the study [ChOIŃSKI, KANIKOWSKI 2004; CHOIŃSKI et al. 2015; GLAZIK et al. 2006; ŁYCZKOWSKA 2009; SKOWRON 2011].

The observations of surface water temperature, its vertical distribution in hourly intervals were also carried out during the stationary and expeditionary measurements. In total, 2800 whole day observations of temperature were conducted, $11 \%$ of which referred to short-term observations.

The analysed lakes are located in the northern part of Poland $\left(\varphi-51^{\circ} 53^{\prime}-54^{\circ} 42^{\prime} \mathrm{N}, \lambda-16^{\circ} 01^{\prime}-\right.$ $23^{\circ} 25^{\prime} \mathrm{E}$ ), in the area of the last Vistulian glaciation. The lakes presented in the study are all postglacial lakes, and differ from one another with respect to basic morphometric properties (Tab. 1). The areas of the lakes range from 51 ha (Lake Świekatowskie) to 7020 ha (Lake Łebsko), whereas their mean depth values vary between $1.6 \mathrm{~m}$ (Lake Lebsko) and over $38 \mathrm{~m}$ (Lake Hańcza), and maximum depth values range from $6.3 \mathrm{~m}$ (Lake Łebsko) to $106.1 \mathrm{~m}$ (Lake Hańcza).

The extent of the littoral zone and its percentage share in the lake volume plays a considerable role in

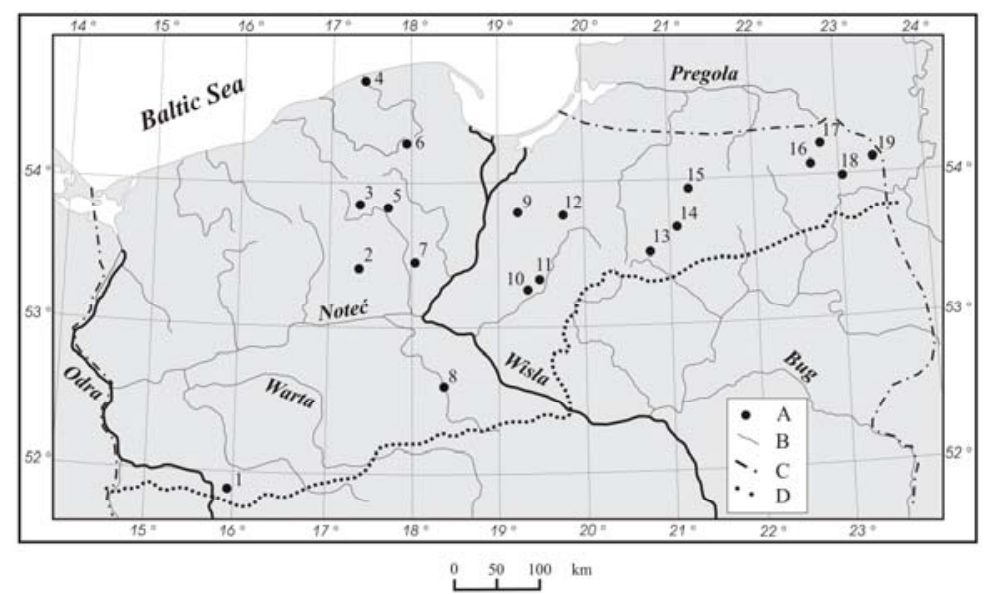

Fig. 1. Distribution of lakes under observations of 24-hour course; $A=$ lakes ( 1 = Sławskie, 2 = Więcborskie, 3 = Brzeźno, $4=$ Łebsko, $5=$ Ostrowite, $6=$ Raduńskie Górne, $7=$ Świekatowskie, $8=$ Gopło, $9=$ Dzierzgoń, $10=$ Wysokie Brodno, $11=$ Bachotek, $12=$ Jeziorak, $13=$ Starokiejkuckie, $14=$ Babięty Wielkie, $15=$ Głębokie, $16=$ Okmin, $17=$ Hańcza, $18=$ Wigry, $19=$ Gaładuś), $\mathrm{B}=$ rivers, $\mathrm{C}=$ Polish border, $\mathrm{D}=$ maximum extent of the Vistulian Glaciation; source: own elaboration 
Table 1. Geographical and morphometric parameters of the lakes studied

\begin{tabular}{|c|c|c|c|c|c|c|c|c|}
\hline No & Lake & $\begin{array}{c}\text { Latitude N } \\
\varphi\end{array}$ & $\begin{array}{c}\text { Longitude E } \\
\lambda\end{array}$ & $\begin{array}{c}\text { Area } \\
\text { ha }\end{array}$ & $\begin{array}{l}\text { Volume } \\
\text { thous. } \mathrm{m}^{3}\end{array}$ & $\begin{array}{c}\text { Maximal depth } \\
\mathrm{m}\end{array}$ & $\begin{array}{l}\text { Mean depth } \\
\mathrm{m}\end{array}$ & $\begin{array}{l}\text { Lake volume } \\
\text { up to } 1.0 \mathrm{~m} \\
\text { (\%) depth }\end{array}$ \\
\hline 1 & Sławskie $^{1)}$ & $51^{\circ} 53^{\prime}$ & $16^{\circ} 01^{\prime}$ & 822.5 & 43664.8 & 12.3 & 5.2 & 9.4 \\
\hline 2 & Więcborskie & $53^{\circ} 21^{\prime}$ & $17^{\circ} 31^{\prime}$ & 195.0 & 16206.2 & 18.5 & 8.4 & - \\
\hline 3 & Brzeźno & $53^{\circ} 58^{\prime}$ & $17^{\circ} 49^{\prime}$ & 67.0 & 3146.9 & 9.7 & 4.5 & 11.7 \\
\hline 4 & Łebsko $^{1)}$ & $54^{\circ} 42^{\prime}$ & $17^{\circ} 23^{\prime}$ & 7020.0 & 117521.0 & 6.3 & 1.6 & 19.2 \\
\hline 5 & Ostrowite $^{1)}$ & $53^{\circ} 48^{\prime}$ & $17^{\circ} 36^{\prime}$ & 259.0 & 29989.8 & 43.0 & 10.7 & 11.1 \\
\hline 6 & Raduńskie Górne $^{1)}$ & $54^{\circ} 14^{\prime}$ & $17^{\circ} 59^{\prime}$ & 362.5 & 60158.7 & 43.0 & 15.5 & 5.3 \\
\hline 7 & Świekatowskie & $53^{\circ} 25^{\prime}$ & $18^{\circ} 05^{\prime}$ & 51.0 & 2843.2 & 11.5 & 5.6 & - \\
\hline 8 & Gopło & $52^{\circ} 37^{\prime}$ & $18^{\circ} 21^{\prime}$ & 2121.5 & 78497.0 & 16.6 & 3.6 & 24.9 \\
\hline 9 & Dzierzgoń & $53^{\circ} 47^{\prime}$ & $19^{\circ} 14^{\prime}$ & 837,5 & 50952,7 & 15.0 & 6.4 & 14,7 \\
\hline 10 & Wysokie Brodno & $53^{\circ} 19^{\prime}$ & $19^{\circ} 23^{\prime}$ & 85.0 & 6691.5 & 22.0 & 7.2 & 7.1 \\
\hline 11 & Bachotek $^{1)}$ & $53^{\circ} 18^{\prime}$ & $19^{\circ} 28^{\prime}$ & 215.0 & 15394.2 & 24.3 & 7.2 & 6.3 \\
\hline 12 & Jeziorak & $53^{\circ} 43^{\prime}$ & $19^{\circ} 37^{\prime}$ & 3152.5 & 141594.2 & 12.9 & 4.1 & 7.8 \\
\hline 13 & Starokiejkuckie $^{1)}$ & $53^{\circ} 38^{\prime}$ & $21^{\circ} 04^{\prime}$ & 30.0 & 3795.6 & 30.2 & 11.5 & 7.8 \\
\hline 14 & Babięty Wielkie & $53^{\circ} 43^{\prime}$ & $21^{\circ} 07^{\prime}$ & 258.5 & 59971.3 & 65.2 & 23.9 & 4.5 \\
\hline 15 & Głębokie & $53^{\circ} 52^{\prime}$ & $21^{\circ} 16^{\prime}$ & 24.0 & 3051.4 & 36.8 & 12.0 & 9.0 \\
\hline 16 & Okmin $^{1)}$ & $54^{\circ} 09^{\prime}$ & $22^{\circ} 50^{\prime}$ & 104.0 & 15295.0 & 39.9 & 13.4 & 3.5 \\
\hline 17 & Hańcza $^{1)}$ & $54^{\circ} 16^{\prime}$ & $22^{\circ} 49^{\prime}$ & 291.5 & 120364.1 & 106.1 & 38.7 & 6.0 \\
\hline 18 & Wigry & $54^{\circ} 10^{\prime}$ & $23^{\circ} 06^{\prime}$ & 2115.0 & 336726.7 & 74.2 & 15.4 & 12.3 \\
\hline 19 & Gaładuś & $54^{\circ} 10^{\prime}$ & $23^{\circ} 25^{\prime}$ & 552.5 & 71817.5 & 54.8 & 12.6 & 30.8 \\
\hline
\end{tabular}

1) Stationary measurements. Explanations: “-” no data.

Source: own study.

the process of water warming and cooling. This property is best expressed by the percentage share of the area of the lakes to the depth of $1.0 \mathrm{~m}$. The biggest share $(>20 \%)$ can be observed in lakes Gopło and Gaładuś, while the lowest share $(<5 \%)$ can be recorded in the deepest lakes (Okmin and Babięty Wielkie).

\section{RESULTS AND DISCUSSION}

Very big changeability of the thermal state of the lakes is an important property of the thermal regime. Every single measurement of water temperature in a lake regardless of the range and character refers to a different weather situation. Considerable changeability of meteorological conditioning causes continuous changes in the thermal structure of water, particularly from mid-April to mid-September. Solar radiation is the main source of thermal energy in surface waters, whereas evaporation from water surface is the main source of heat reduction. The increase in surface water temperature is mainly influenced by the dominance of absorbed net radiation over evaporation, whereas heat reduction primarily results from the dominance of thermal energy loss over the absorption of radiation. The mean daily cycle of water temperature in the stagnant water bodies resembles most frequently a sine loop.

The direction of heat exchange between surface water and the air over it is defined by differences in temperature between the two environments. In the daily course, most frequently from mid-March, the average number of hours with the dominance of air temperature over water temperature equals 4-5 hours, whereas in May even amount to 10-11 hours at the end of April [SZUMIEC 1984]. The examinations con- ducted on Lake Bachotek in the first half of May in the years 2004-2006 confirm these findings. The differences reached 9-12 hours in favour of air temperature. In the summer season air temperature was higher than surface water temperature on average between 8:00-19:00 (7:00-18:00 GMT), whereas maximal differences reached even $8-10^{\circ} \mathrm{C}$. There were also reverse situations when air temperature was clearly lower than water temperature for the whole day (approx. $12-14 \%$ of records).

Relations between monthly average temperature values of surface water in lakes and air temperature. Neighbouring posts indicated a close dependence between these factors. These relations are mainly determined by the morphometry of lake basins; especially the average depth, the lake surface, and geometric depth indicator (Fig. 2).

Application of mean period values of air and water temperatures demonstrated the complexity of the problem and permitted a more accurate presentation of the relations and processes resulting from climate warming [DĄBROWSKI et al. 2004].

The differences in temperatures between the littoral zone and the open parts (the pelagial zone) depend upon several factors, the most important of which relate to the character of those two zones, and to the development and extent of the littoral zone in particular [GIEYSZTOR 1960]. During spring and summer warming these differences in the afternoon may reach $3.0-3.5^{\circ} \mathrm{C}$, rarely more. Due to water mixing the differences range from 0.8 to $1.5^{\circ} \mathrm{C}$. Relatively considerable differences in surface water temp eratures were also observed very often in summer (lakes: Gopło, Wigry, Ostrowskie). 

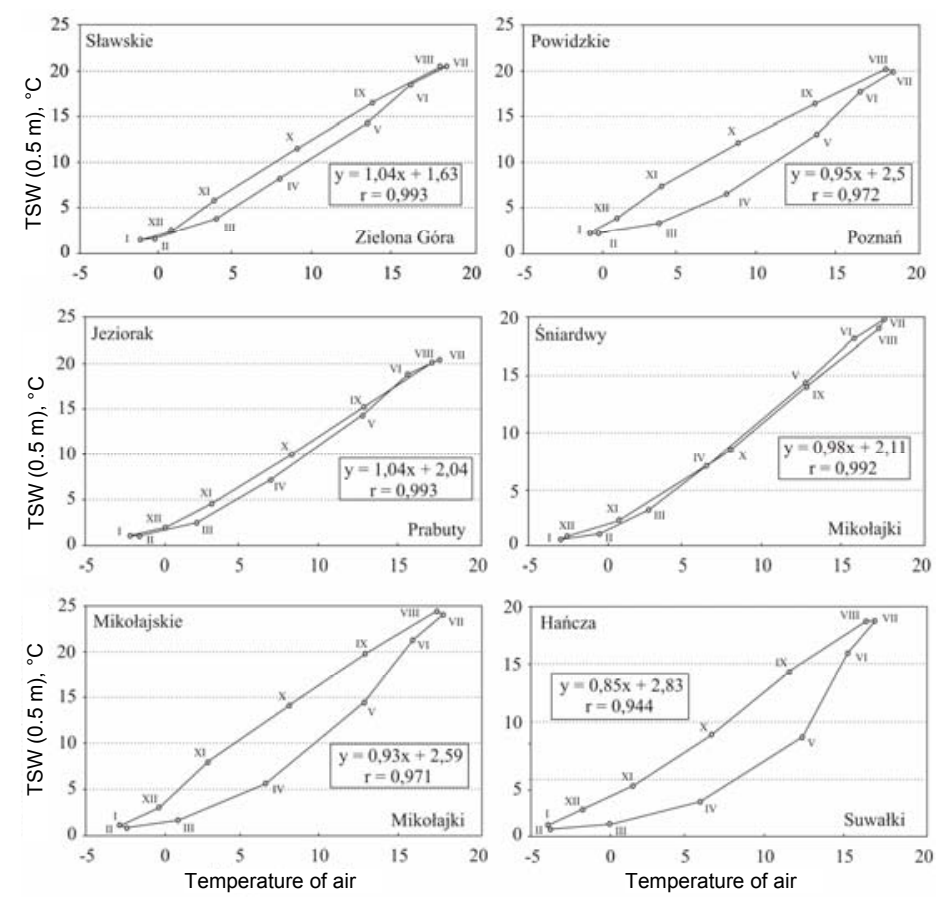

Fig. 2. Dependence between the mean monthly values of temperature of surface water (TSW) in lakes and air temperature in period

1971-2015 (statistical significance $\alpha<0.001$ ); source: own study

Examples of differences in water temperature between the littoral and the pelagic zone in the daily course, indicating several lakes of different morphometry (Tab. 2). In general, the temperature of the surface water $(0.5 \mathrm{~m})$ during the summer rarely exceeded $2^{\circ} \mathrm{C}$.

Table 2. Mean daily surface water temperature $(0.5 \mathrm{~m})$ at the littoral station (L) and the pelagial station $(\mathrm{P})$ on the selected examples (calculated on the grounds of the measurements carried out every 30 minutes)

\begin{tabular}{|c|c|c|c|c|}
\hline \multirow{2}{*}{$\begin{array}{l}\text { Lake } \\
\text { (code) }\end{array}$} & \multirow{2}{*}{ Date } & \multicolumn{2}{|c|}{ Water temperature, ${ }^{\circ} \mathrm{C}$} & \multirow{2}{*}{$\begin{array}{l}\text { Difference } \\
\text { of tempera- } \\
\text { ture }(\mathrm{L}-\mathrm{P})\end{array}$} \\
\hline & & $\mathrm{L}$ & $\mathrm{P}$ & \\
\hline $\begin{array}{l}\text { Bachotek } \\
\text { (II-49-64) }\end{array}$ & $\begin{array}{c}25.07- \\
2.08 .1989\end{array}$ & 21.8 & 20.3 & 1.5 \\
\hline $\begin{array}{l}\text { Brzeźno } \\
\text { (I-28-10) }\end{array}$ & $14-17.07 .2005$ & 23.3 & 20.6 & 2.7 \\
\hline $\begin{array}{l}\text { Gaładuś } \\
\text { (II-19-68) }\end{array}$ & $26-30.06 .1997$ & 22.4 & 19.6 & 2.8 \\
\hline $\begin{array}{l}\text { Gopło } \\
\text { (III-23-1) }\end{array}$ & $7-10.07 .1998$ & 18.8 & 17.5 & 1.3 \\
\hline $\begin{array}{l}\text { Hańcza } \\
\text { (II-9-20) }\end{array}$ & 16-20.07.1997 & 22.6 & 21.6 & 1.0 \\
\hline $\begin{array}{l}\text { Jeziorak } \\
\text { (II-32-41) }\end{array}$ & $26-28.07 .2005$ & 24.2 & 22.8 & 1.5 \\
\hline $\begin{array}{l}\text { Wigry } \\
\text { (II-19-1) }\end{array}$ & $8-12.08 .1995$ & 23.4 & 21.3 & 2.1 \\
\hline
\end{tabular}

${ }^{1)}$ Lake codes acc. to CHOIŃSKI [2006].

Source: own study.

The conducted investigations prove that generally water surface layers which are subject to continuous mixing do not favour the development of big dif- ferences between the two zones. During the daily course the maximal difference in favour of the temperature of the littoral zone occurred most often from 10:00-11:00 to 21:00-22:00, with the maximum between 15:00-16:00. In general, the temperature over the pelagial zone at 7:00 (6:00 GMT) is higher by $0.2-0.6^{\circ} \mathrm{C}$ in relation to the littoral zone. The examples of such distributions are presented in Figures 3 and 4.

The course of the temperatures of surface layers indicates that on average the maximum was recorded between 14:00 and 17:00 (13:00 and 16:000 GMT). With sunny weather the maximum tended to move to 18:00 (17:00 GMT), whereas with low weather the maximum was often recorded between 13:00 and 14:00 (12:00 and 13:00 GMT). During intense wind mixing the maximal temperature stabilised most often between 14:00 and 15:00 (13:00-14:00 GMT). The minimal temperature values followed the course of air temperature. These values were most often observed between 6:00 and 7:00 (5:00-6:00 GMT). With windy and rainy weather the minimum was delayed by 1-2 hours (Fig. 5).

The term of the occurrence of the mean day value appears to be an interesting issue. Many measurements indicated that the mean value was recorded twice during a day. It was observed between 8:00 and 11:00 (7:00 and 10:00 GMT) for the first time, and for the second time in the evening between 20:00 and 22:00 (19:00 and 21:00 GMT).

Day measurements of water temperature show that its day fluctuations during summer reach $2-3^{\circ} \mathrm{C}$, and rarely exceed $4^{\circ} \mathrm{C}$. During intense insolation and windless weather conditions they may even reach $5.5^{\circ} \mathrm{C}$, whereas when the weather is cloudy and there are waves these fluctuations often range from 0.8 to $2.0^{\circ} \mathrm{C}$. The examples of the daily course of air temperature and surface water temperature are presented on data from of polymictic Lake Jeziorak with various weather conditions during summer stagnation (Fig. 6).

Similar values are recorded in spring when intense water warming takes place. Temperature amplitudes are usually lower (by $0.3-1.2^{\circ} \mathrm{C}$ ) in the littoral zone than in the pelagial zone. The examples of the daily courses of surface water temperature in the pelagial zones of the selected lakes prove the above findings (Fig. 7).

The daily course of temperature in vertical distribution, utilizing the polymictic Lake Gopło and the bradymictic Lake Hańcza (Fig. 8, 9) as examples. In both cases, it was observed that the largest change in daily temperature occurred at a depth of 4-8 m (average $2.5-3.5^{\circ} \mathrm{C}$ ). This is confirmed by the amount of temperature pulsation observed in hourly intervals, which were calculated for several lakes (Tab. 3, 4). 


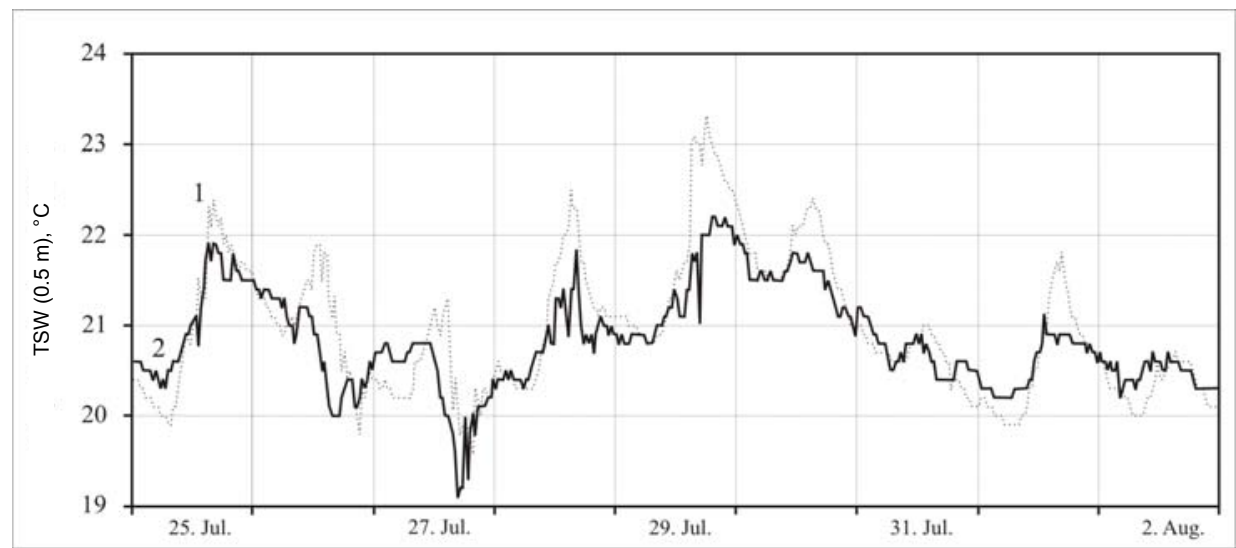

Fig. 3. Day course of the temperature of surface water (TSW 0.5 m) of Lake Bachotek in the summer of 1989: $l=$ a stand within the littoral zone, 2 = a stand within the pelagial zone; source: own study

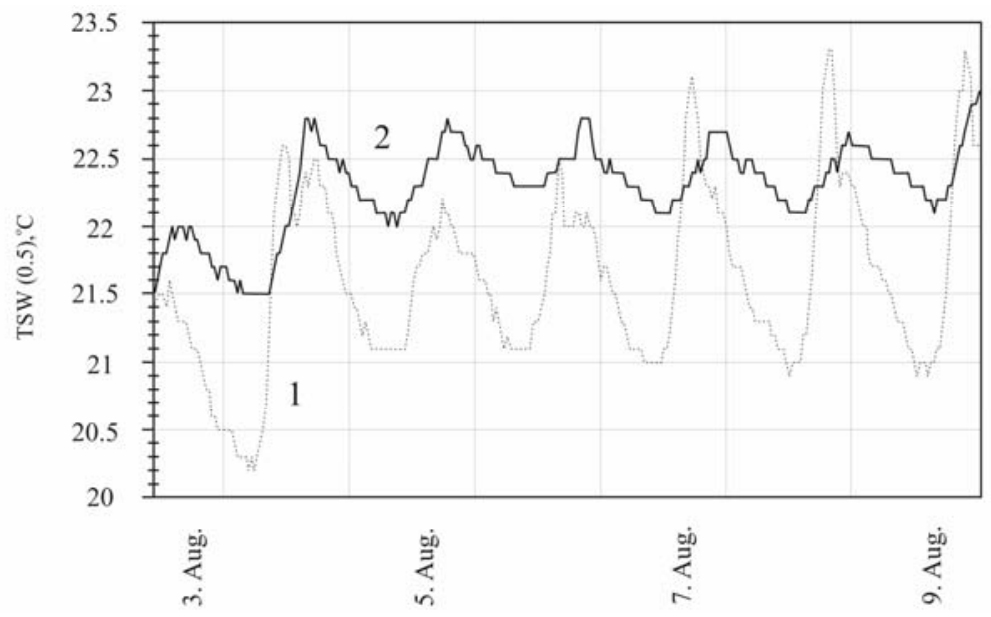

Fig. 4. Day course of the temperature of surface water (TSW $0.5 \mathrm{~m}$ ) of Lake Hańcza in autumn of 2009: $l=$ a stand within the littoral zone, 2 = in the open part of the lake; source: own study
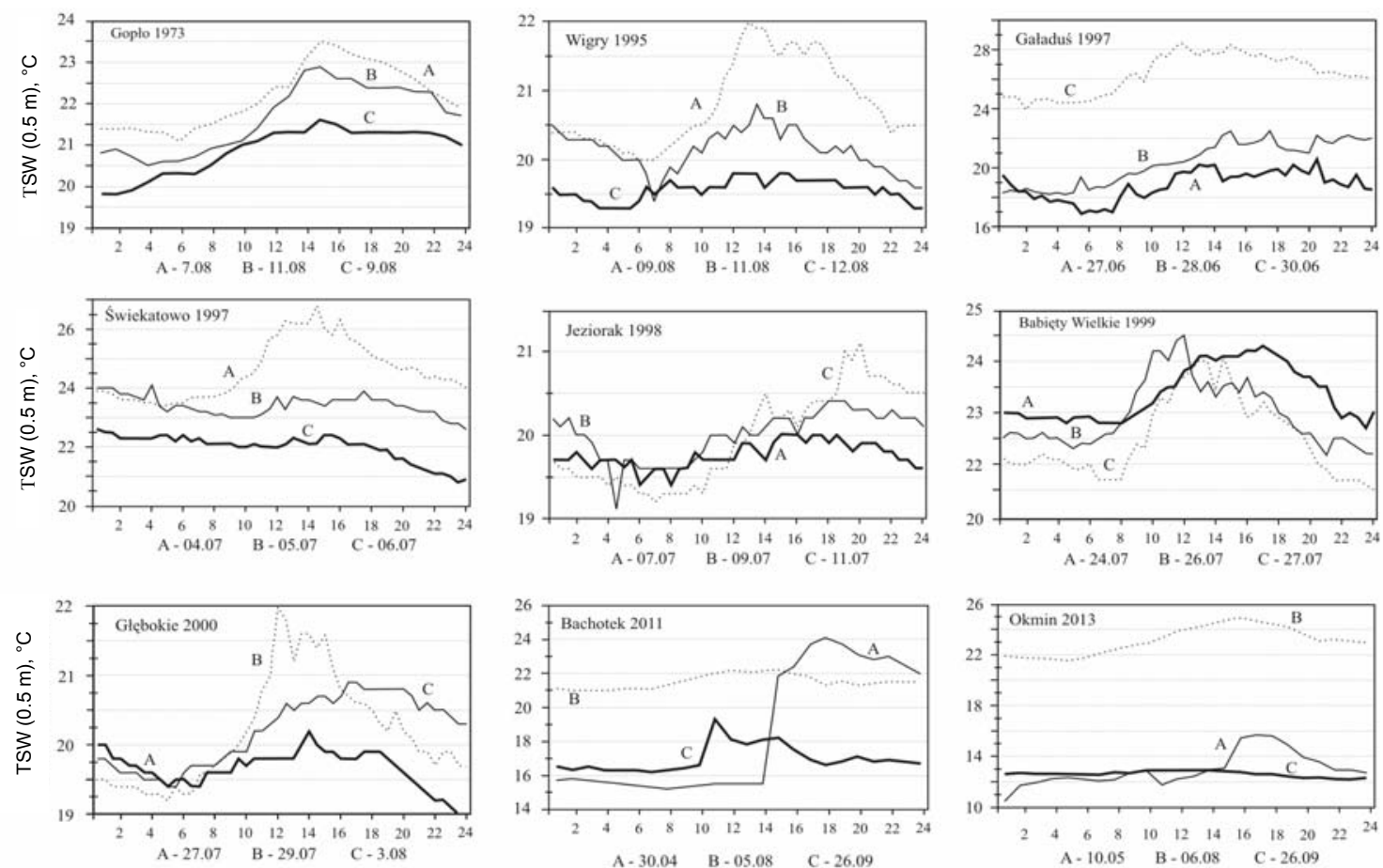

Fig. 5. Course of daily surface water temperature (TSW $0.5 \mathrm{~m}$ ) in the littoral zone in various periods of the yearly cycle in the selected lakes located in the Polish Lowland; source: own study 


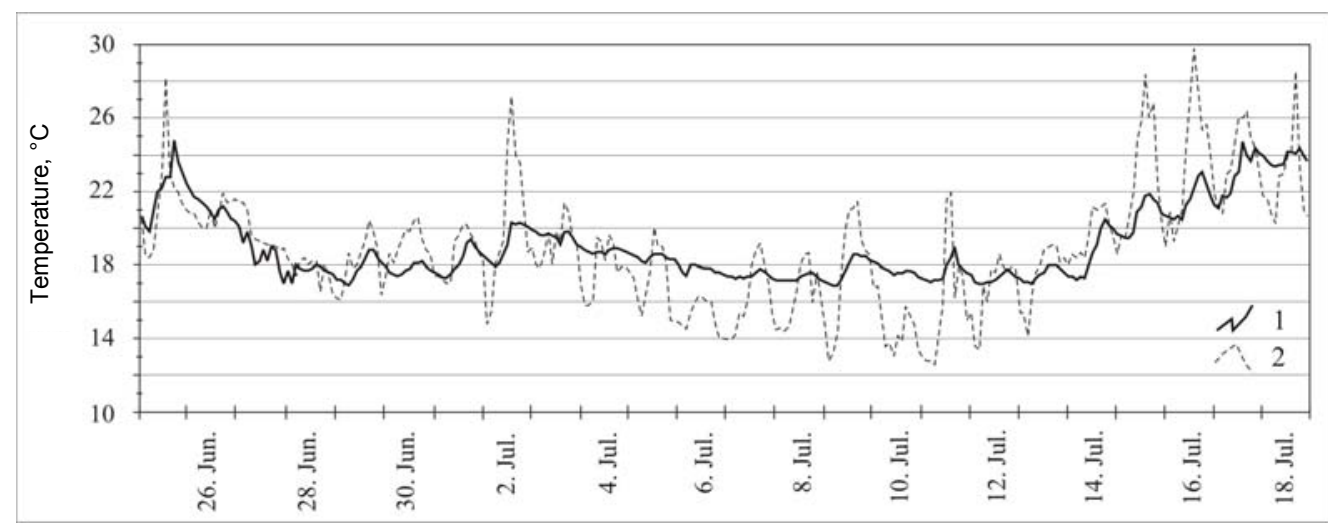

Fig. 6. Course of the temperature of surface water (TSW $0.5 \mathrm{~m}$ ) of Lake Jeziorak (1) and air temperature (2) in the southern part of the lake in the summer of 2007; source: own study
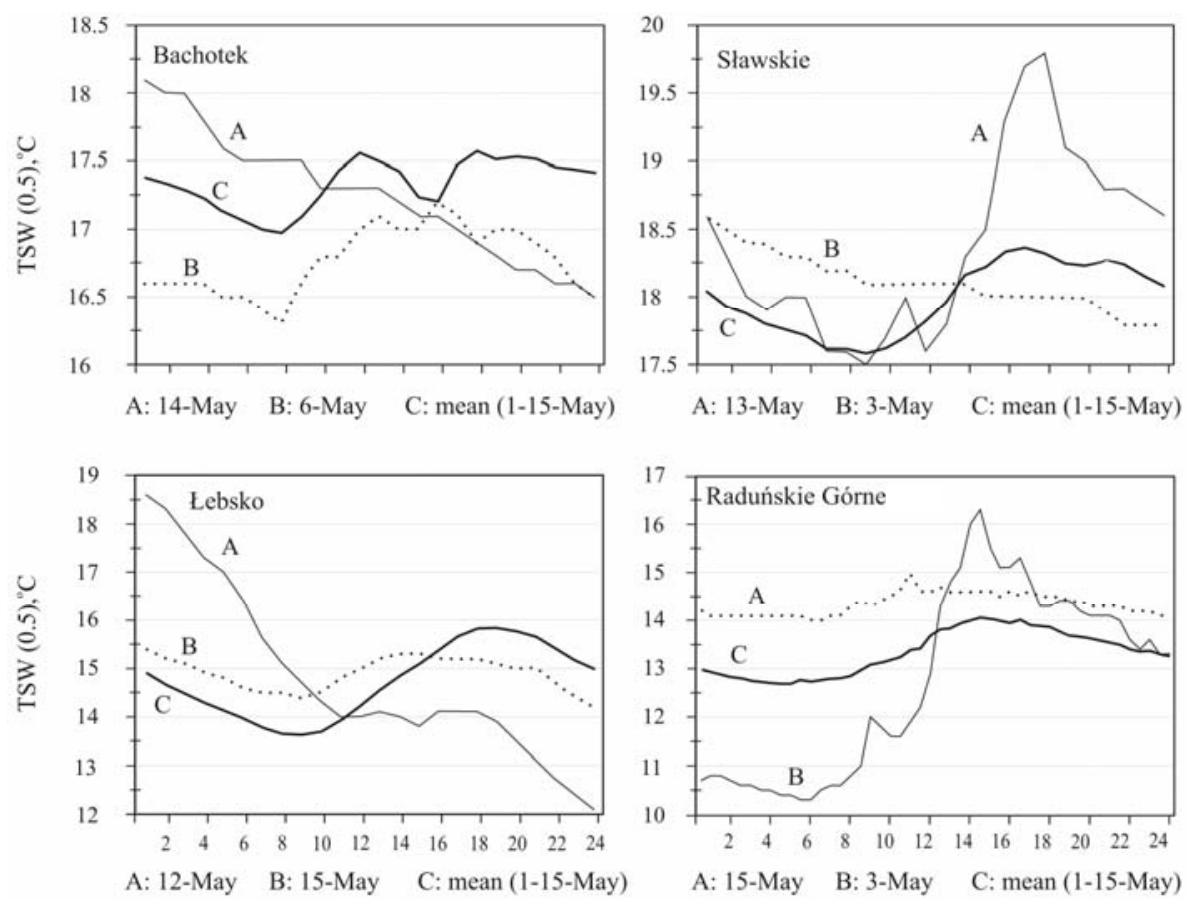

Fig. 7. Day course of the temperature of surface water (TSW $0.5 \mathrm{~m}$ ) in selected lakes at evaporometric station in the first half of May 2012; source: own study

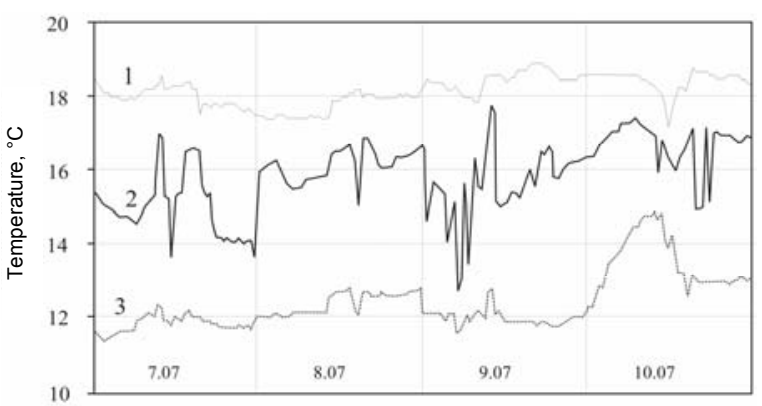

Fig. 8. Course of the temperature of water in the deepest point of the Lake Gopło at the depth of: $1 \mathrm{~m}(1), 10 \mathrm{~m}(2)$, 15 m (3) in July 1998;

source: SKOWRON [2011], modified

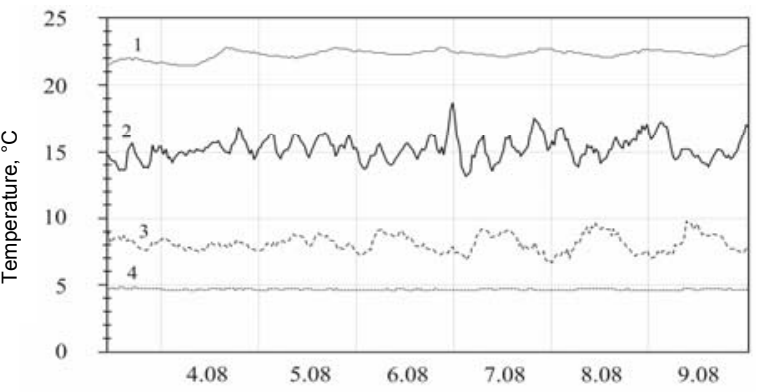

Fig. 9. Day course of water temperature of Lake Hańcza in August 2009 at the selected depths: $0.5 \mathrm{~m}(1), 8 \mathrm{~m}(2)$, $13 \mathrm{~m} \mathrm{(3),} 30 \mathrm{~m} \mathrm{(4)}$; source: SKOWRON [2011], modified 
Table 3. The number of water pulsations $\left(\geq 0.5^{\circ} \mathrm{C}\right)$ in hourly intervals in 2006 (pulsations of $\geq 3^{\circ} \mathrm{C}$ were given in brackets) in Lake Bachotek

\begin{tabular}{|l|c|c|c|c|c|c|c|}
\hline \multirow{2}{*}{ Month } & \multicolumn{7}{|c|}{ Depth, m } \\
\cline { 2 - 8 } & 0,5 & 1 & 2 & 4 & 6 & 8 & 13 \\
\hline January & 0 & 0 & 0 & 0 & 0 & 0 & 0 \\
\hline February & 0 & 0 & 0 & 0 & 0 & 0 & 0 \\
\hline March & 4 & 1 & 5 & $5(1)$ & 0 & 4 & 5 \\
\hline April & 30 & 30 & $23(1)$ & 52 & 18 & 5 & 3 \\
\hline May & 27 & 31 & 53 & $280(12)$ & $153(3)$ & 17 & 1 \\
\hline June & 35 & 26 & 47 & $166(9)$ & $322(14)$ & 26 & 1 \\
\hline July & 34 & 30 & 36 & $205(4)$ & $356(5)$ & 40 & 2 \\
\hline August & 11 & 4 & 3 & 16 & $183(3)$ & 17 & 0 \\
\hline September & 4 & 1 & 1 & 1 & 42 & $131(2)$ & 0 \\
\hline October & 0 & 0 & 0 & 0 & 3 & 61 & 0 \\
\hline November & 0 & 0 & 0 & 0 & 0 & 0 & 8 \\
\hline December & 0 & 0 & 0 & 0 & 0 & 0 & 0 \\
\hline \multicolumn{1}{|c|}{ Total } & $\mathbf{1 4 5}$ & $\mathbf{1 2 3}$ & $\mathbf{1 6 2}$ & $\mathbf{2 1 8}$ & $\mathbf{2 2 5}$ & $\mathbf{1 9 0}$ & $\mathbf{2 0}$ \\
\hline
\end{tabular}

Source: SKOWRON [2011], modified.

Table 4. The number of water temperature pulsations $\left(\geq 0.5^{\circ} \mathrm{C}\right)$ in hourly intervals in the selected lakes from 15 VII to 15 VIII 2005

\begin{tabular}{|c|c|c|c|c|c|c|c|c|}
\hline Parameter & \multicolumn{8}{|c|}{ Value } \\
\hline \multicolumn{9}{|c|}{ Lake Bachotek (II-49-64) } \\
\hline Depth, m & 0.5 & 1 & 2 & 4 & & & 8 & 13 \\
\hline $\begin{array}{l}\text { The number } \\
\text { of pulsa- } \\
\text { tions }\end{array}$ & 12 & 5 & 12 & 61 & & & 53 & 0 \\
\hline \multicolumn{9}{|c|}{ Lake Ostrowite (I-36-81) } \\
\hline Depth, m & 0.5 & 2 & 4 & 6 & 8 & 11 & 18 & 35 \\
\hline $\begin{array}{l}\text { The number } \\
\text { of pulsa- } \\
\text { tions }\end{array}$ & 7 & 8 & 2 & 57 & 104 & 14 & 2 & 1 \\
\hline \multicolumn{9}{|c|}{ Lake Starokiejkuckie (II-44-77) } \\
\hline Depth, m & 0.5 & 1 & 2 & 4 & 7 & 11 & 1 & 28 \\
\hline $\begin{array}{l}\text { The number } \\
\text { of pulsa- } \\
\text { tions }\end{array}$ & 19 & 6 & 2 & 50 & 166 & 1 & 0 & 0 \\
\hline
\end{tabular}

Explanations: lake codes acc. to CHOIŃSKI [2006].

Source: SKOWRON [2011], modified.

\section{CONCLUSIONS}

The course of water temperature in the lakes shows seasonality and sinusoidal rhythm. This rhythm also concerns its daily course. The investigations of water thermal conditions were conducted on the lakes with various morphometric properties during the periods free of ice phenomena, and during ice-on periods. The obtained results show numerous significant properties determining a hydrological regime of lake ecosystems.

1. In the surface water layer there are distinct difference with respect to time and spatial distribution. The biggest diversity in lake temperature was observed during spring warming, and it exceeded $4-5^{\circ} \mathrm{C}$. During the remaining periods of the yearly cycle it rarely went over $2^{\circ} \mathrm{C}$, and oscillated between $0.8-1.2^{\circ} \mathrm{C}$ on average.

2. During the daily course of air temperature directly above the water table and in the surface layer of the lakes most frequently from late April there may be even up to 9-12 hours in favour of air temperature. During summer season air temperature was higher than surface water temperature an average between 8:00 and 19:00 (7:00-18:00 GMT), whereas maximal differences reached even $8-10^{\circ} \mathrm{C}$. There were also reverse situations, when air temperature was evidently lower than water temperature (approx. 9-12\% of the records).

3. During the periods free of ice phenomena, the temperature in the littoral zone is most often higher than the temperature in the pelagial zone (between 14:00 and 20:00 (13:00-19:00 GMT), though it is lower between 5:00 and 8:00 (4:00-7:00 GMT). In many cases, however, this distribution is more diverse and often unreadable [SKOWRON 2011].

4. In the daily course of surface water temperature its highest values are recorded between 15:00 (14:00 GMT) and 18:00 (17:00 GMT), whereas its lowest values are most often recorded at 5:00 (4:00 GMT) and 7:00 (6:00 GMT).

5 . The mean day value (calculated on the grounds of 2800 daily observation series of the surface water temperature) occurs twice: in the morning between 8:00 (7:00 GMT) and 11:00 (10:00 GMT) and in the late evening between 20:00 (19:00 GMT) and 22:00 (21:00 GMT).

6 . Changes in the daily course of water temperature can be clearly seen down to the depth of 2.5-3.5 $\mathrm{m}$, whereas are just perceivable down to $5.5-7.0 \mathrm{~m}$. This range must be related to the dynamics of meteorological conditions which mainly determine the depth of wind mixing.

7. The biggest increases in water temperature occurred in the first half of May, whereas the biggest declines were recorded at the turn of September and October. These facts correspond with the number of temperature pulsation $\geq 0.4^{\circ} \mathrm{C}$, which decisively dominate in spring warming (the second half of April) with respect to the number of pulsations in the remaining periods.

8. Daily amplitudes of surface water temperature which range from $0.8-2.0^{\circ} \mathrm{C}$ constitute a very important element of the thermal regime which varies in the particular lakes, particularly during spring warming and summer stagnation.

\section{REFERENCES}

CholŃski A. 2006. Katalog jezior Polski [Catalogue of lakes of Poland]. Poznań. Wydaw. Nauk. UAM. ISBN 8323217327 pp. 599.

CHOIŃSKI A., KANIKOwSKI J. 2004. Fluctuations in water temperature of Lake Zamkowe. Limnological Review. Vol. 4 p. 33-44.

Choiński A., PtAK M., StrzelczaK A. 2015. Changeability of accumulated heat content in Alpine - type lakes. Polish Journal of Environmental Studies. Vol. 24 (6) p. 2363-2369.

CHOJNOWSKI S. 1967. Uwagi o zmianach temperatury wody jeziornej [Notes on temperature changes water lake]. 
Wiadomości Służby Hydrologiczno-Meteorologicznej. Nr 3 (1) p. 53-59.

Dąbrowski M., Marszelewski W., Skowron R. 2004. The trends and dependencies between air and water temperatures in the lakes located in Northern Poland in the years 1961-2000. Hydrology and Earth System Sciences. Vol. 8. Nr 1 p. 79-87.

DMOchowsKi M., SZyjKOwSKi A., RÖSLER A. 1988. Głębokość średnia jako wskaźnik dynamiki zbiorników wodnych [Mean depth as the element of water dynamice in water reservoirs]. Wiadomości IMGW. Nr 11 (3-4) p. $37-47$.

GIEYSZTOR M. 1960. On the thermal conditions of the littoral zone of lakes. Polskie Archiwum Hydrobiologii i Rybactwa. Vol. 8 p. 171-193.

GLAZIK R., MARSZELEWSKI W., SKOWRON R. 2006. Selected problems of registration of vertical distribution of water temperatures in lakes. Limnological review. Vol. 6 p. $103-110$.

GRZEŚ M. 1976. Krótkookresowe zmiany temperatury wód jeziornych i stabilności masy wodnej w świetle punktowych pomiarów na jeziorze Gopło [Short-term changes in lake-waters and in stability of the water mass, determined by spot measurements made at Lake Gopło]. Przegląd Geograficzny. Nr 48 p. 435-456.

KONDRACKI J. 1952. Obserwacje nad termiką jeziora Niegocin na stacji naukowej Polskiego Towarzystwa Geograficznego w Giżycku (1949-1951) [Observations on thermal conditions of the Lake Niegocin in the research station of Polish Geographical Society in Giżycko (1949-1951)]. Przegląd Geograficzny. Nr 24 (3) p. 49 71.

LANGE W. 1978. Warunki akumulacji ciepła w jeziorach Pojezierza Kaszubskiego [Conditions of heat accumulation in the lakes of the Cassubian Lake Dis- trict]. Zeszyty Naukowe Wydziału Nauk o Ziemi. Geografia. Nr 8 p. $89-108$.

ŁYCZKOwSKA G. 2009. Termika wód Wielkiego Stawu w Karkonoszach [Thermals waters of the Wielki Staw in the Karkonosze Mountains]. Poznań. WN UAM pp. 136.

SKOwRON R. 1999. Termiczna sezonowość wody powierzchniowej w jeziorach polskich - jej fluktuacje $i$ tendencje [Thermal seasonality of surface water in Polish lakes - its fluctuations and trends]. Materiały konferencji limnologicznej w Radzyniu k. Sławy, 20-22 września 1999 r., Warszawa. IMGW p. 231-243.

SKOWRON R. 2000a. Zmiany temperatury wody i zasobów ciepła $\mathrm{w}$ przebiegu dobowym na przykładzie epitermicznego jeziora Gopło [Changes in water temperature and heat resources in the course of daily exemplified epithermic lake Gopło]. Acta Universitatis Nicolai Copernici. Geografia. Z. 31 (106) p. 289-306.

SKOWRON R. 2000b. O dobowej zmienności temperatury wody i zasobów ciepła w jeziorach. W: Naturalne i antropogeniczne przemiany jezior [The diurnal variation in water temperature and heat resources in lakes. In: Natural and anthropogenic transformations of lakes]. Eds H. Gawrońska, K. Lossow. Materiały IV Konferencji Limnologicznej w Zalesiu k. Olsztyna. Olsztyn. UWM p. 45-58.

SKOWRON R. 2011. Zróżnicowanie i zmienność wybranych elementów reżimu termicznego w jeziorach na Niżu Polskim [The differentiation and the changeability of chosen of elements the thermal regime of water in lakes on Polish Lowland]. Toruń. Wydaw. UMK. ISBN 97883-231-2695-9 pp. 345.

SzUMIEC M. 1984. Termika stawów karpiowych [The thermology of ponds the carp]. Warszawa. PWN. ISBN 8301-04187-0 pp. 136.

\section{Rajmund SKOWRON, Adam PIASECKI}

\section{Dynamika dobowego przebiegu temperatury wody $w$ jeziorach w Polsce}

\section{STRESZCZENIE}

Praca dotyczy krótkotrwałych zmian temperatury wody powierzchniowej w jeziorach w Polsce. Została ona opracowana na podstawie eksperymentalnych pomiarów temperatury wody prowadzonych co 60 minut w latach 1971-2015 w 19 jeziorach wytypowanych na podstawie cech morfometrycznych. Badania prowadzono w systemie pomiarów ekspedycyjnych (do 8 dni) i stacjonarnych (ponad 2 miesiące) i obejmowały temperaturę powierzchniową wody oraz jej pionowy rozkład. Na podstawie analizy wyników stwierdzono różnice temperatury wody (amplitudy dobowe) zarówno w rozkładzie czasowym, jak i przestrzennym. Największe różnice temperatury wody występowały w okresie wiosennego nagrzewania i często osiagały $4-5^{\circ} \mathrm{C}$, natomiast w pozostałych okresach cyklu rocznego rzadko przekraczały $2^{\circ} \mathrm{C}$. Na podstawie cogodzinnych pomiarów temperatury wody można stwierdzić, że temperatura przed południem między godziną 8:00 a 11:00 (7:00 a 10:00 GMT) oraz późnym wieczorem w godzinach 20:00-22:00 (19:00-21:00 GMT) była najbardziej zbliżona do średniej dobowej. Zmiany dobowe w rozkładzie pionowym temperatury wody wyraźnie zaznaczają się do głębokości $2,5-3,5 \mathrm{~m}$, natomiast dostrzegane są do głębokości 5,5-7,0 m.

Słowa kluczowe: jeziora, temperatura wody, przebieg dobowy 